\title{
KEMAMPUAN LITERASI STATISTIS MAHASISWA MELALUI PENDEKATAN RIGOROUS MATHEMATICAL THINKING (RMT)
}

\section{(STATISTICAL LITERATION SKILLS OF STUDENTS THROUGH RIGOROUS MATHEMATICAL THINKING (RMT) APPROACH)}

\author{
Frena Fardillah ${ }^{1,2}$, Jozua Sabandar ${ }^{3}$, Elah Nurlaelah ${ }^{4}$ \\ ${ }^{1}$ Mahasiswa Pendidikan Matematika SPS Universitas Pendidikan Indonesia \\ ${ }^{2}$ Dosen Program Studi Teknik Industri, Universitas Muhammadiyah Tangerang \\ ${ }^{3,4}$ Dosen Program Studi Pendidikan Matematika SPS Universitas Pendidikan Indonesia
}

\begin{abstract}
Abstrak
Penelitian ini bertujuan untuk menelaah secara komprehensif pencapaian dan peningkatan kemampuan literasi statistis mahasiswa melalui pendekatan Rigorous Mathematical Thinking (RMT) dan mahasiswa yang mendapat pembelajaran ekspositori. Menelaah perbedaan peningkatan kemampuan literasi statistis antara kelompok RMT dan Ekspositori. Desain penelitian ini adalah kuasi eksperimen, dengan desain penelitian Nonequivalent. Instrumen yang digunakan dalam penelitian ini merupakan tes kemampuan literasi statistis. Penelitian ini dilakukan pada mahasiswa semester empat, pada materi statistika II dengan jumlah mahasiswa sebanyak 48 mahasiswa. Hasil penelitian menunjukkan bahwa kemampuan literasi statistis mahasiswa yang memperoleh pembelajaran dengan pendekatan RMT lebih baik dari mahasiswa yang memperoleh pembelajaran ekspositori. Peningkatan kemampuan literasinya mahasiswa yang memperoleh pendekatan RMT lebih baik, dari pada mahasiswa yang mendapatkan pembelajaran ekspositori bila dilihat secara keseluruhan dan berdasarkan katgori PAM (tinggi, sedang dan rendah). Peningkatan kemampuan literasi statistis mahasiswa berdasakan PAM (tinggi, sedang dan rendah) pada kelas ekperimen meningkat secara merata.
\end{abstract}

Kata Kunci: Pendekatan Rigorous Mathematical Thinking (RMT), Pembelajaran Ekspositori, Kemampuan Literasi Statistis.

\begin{abstract}
This study aims to examine the achievement and improvement of statistical literacy skills through approaches Rigorous Mathematical Thinking (RMT) among the students were given learning Rigorous Mathematical Thinking (RMT) and expository. Determine differences in statistical literacy skills in the classroom Rigorous Mathematical Thinking (RMT) and expository. This research design is quasi-experimental, research design Nonequivalent. instruments used in this research is to test the ability of statistical literacy. Research conducted on students of 4th semesters on materials statistics II and the number of students 48 . The findings of statistical literacy skills were better in group Rigorous Mathematical Thinking (RMT). Overall increase statistical literacy skills better in group Rigorous Mathematical Thinking (RMT), and by category PAM (High, medium and low). Improved statistical
\end{abstract}


literacy skills of students Based PAM (high, medium and low) in Rigorous Mathematical Thinking (RMT) group increased evenly.

Keywords: Rigorous Mathematical Thinking (RMT), expository, Statistical literacy skills.

\section{PENDAHULUAN}

Seiring berkembangnya ilmu pengetahuan dan teknologi yang semakin cepat, menjadikan peranan matematika dan statistika sangat penting. Sehingga baik di sekolah maupun di perguruan tinggi matematika dan statistika menjadi sorotan yang paling utama. Bila kita menelaah konten materi yang diberikan dalam mata kuliah statistika, maka tidak sedikit mahasiswa yang merasa kesulitan dalam menyelesaikan permasalahan tersebut, bahkan ada yang memiliki pandangan bahwa matematika sulit dan tidak menyenangkan. Anggapan akan sulitnya matematika dan statistika membuat mahasiswa tidak ingin mempelajarinya, bahkan menghindarinya.

Perkembangan bidang keilmuan menuntut peranan statistika untuk memperhitungkan peluang kejadian yang mungkin akan terjadi, memprediksi, memperhitungkan hubungan dari kausalitas, menjawab serta memberikan solusi dari segala permasalahan yang terjadi dalam kehidupan. Sehingga peranan statistika menjadi sanggat penting, khususnya di perguruan tinggi.

Di sekolah, statistika dan matematika menjadi satu dalam mata pelajaran matematika. Namun di perguruan tinggi, statistika di ajarkan secara terpisah. Hal ini menunjukkan bahwa begitu pentingnya statistika, sehingga membutuhkan kajian secara mendalam untuk mempelajarinya. Pentingnya peranan statistika juga sejalan dengan pendapat More (1997), bahwa dalam bidang ke ilmuan, khususnya statistika mampu memberikan solusi dari fenomena yang ada dalam kehidupan, dan dalam pengetahuan itu sendiri.

Di perguruan tinggi, pentingnya ilmu statistika semakin terlihat dan menjadi sangat penting manakala seorang peneliti mengajukan hipotesa sementara dari penelitian yang akan ia lakukan. Dalam dunia penelitian peranan statistika sangat diperlukan baik dalam metode maupun dalam perhitungan. Sudjana (2005:2) mengemukakan bahwa statistika sangat diperlukan bukan saja hanya dalam penelitian atau riset, tetapi juga perlu dalam bidang pengetahuan lainnya seperti: teknik, industri, ekonomi, astronomi, biologi, kedokteran, asuransi, pertanian, perniagaan, bisnis, sosiologi, antropologi, pemerintahan, pendidikan, psikologi, meteorologi, geologi, farmasi, ekologi, pengetahuan alam, pengetahuan sosial dan lain sebagainya.

Sejalan dengan Sudjana terkait pentingnya statistika, Rumsey (2000) berpendapat bahwa dalam pembelajaran statistika memerlukan beberapa kompetensi dasar yang harus dicapai yaitu: (1) kesadaran terhadap pentingnya pemahaman tentang data; (2) memahami konsep dasar statistika dan terminologinya; (3) memiliki pengetahuan tentang cara pengumpulan data dan mendeskripsikannya; (4) memiliki keterampilan menginterpretasi; (5) sebagai dasar komunikasi. Sehingga para mahasiswa calon guru matematika perlu memiliki kemampuan ststistis yang baik dalam pembelajaran statistik, hal ini dikarenakan begitu pentingnya statistiska dalam reserch yang akan dilakukan oleh mahasiswa tersebut. Pemahaman tentang data, konsep dasar statistika, cara 
mengumpulkan data, cara menginterpretasikan data, serta bagaimana mengkomunikasikan data tersebut.

Begitu pentingnya statistika dalam menjawab permasalahan yang ada menuntut berkembangnya kemampuan literasi statistis. Literasi menurut Kern (Takaria, 2015) merupakan suatu penggunaan praktek-praktek situasi sosial, historis, dan kultural dalam menciptakan dan menginterpretasikan makna melalui teks. Farmer \& Stricevic (2011) menjelaskan bahwa UNESCO berpendapat kemampuan literasi merupakan kemampuan untuk memahami informasi, mengidentifikasi, menafsirkan, mengkomunikasikan, dan menghitung melalui sumber yang diperoleh dari media cetak dan mampu menulis dalam berbagai konteks. Seiring dengan kemajuan ilmu pengetahuan, maka pemahaman literasi terus berkembang sesuai dengan kebutuhan setiap bidang ilmu pengetahuan, diantaranya: literasi media, literasi sains, literasi informasi, literasi matematis, serta literasi statistis (melek statistis).

Seorang mahasiswa yang terbiasa dengan statistik, maka secara tidak langsung ia mulai terbiasa berfikir dan mengambil sikap dengan statistika, sehingga mahasiswa akan memiliki kecendrungan (sikap) statistik dalam menyelesaikan permasalah dan mengambil keputusan dari permasalahan yang sedang di hadapi.

Suryadi (2005) menjelaskan bahwa pembelajaran dengan pendekatan secara umum terdiri atas tiga kelompok, yaitu: 1) Pembelajaran langsung, 2) Pembelajaran tidak langsung, 3) Gabungan. Pembelajaran dengan pendekatan (RMT) lebih menekankan pada teori konruktivisme yang memilik tiga fase, yaitu: 1) Pengembangan Kognitif (Cognitif Development), dimana mahasiswa membangun pengetahuan kognitif, 2) Konten sebagai Proses (Content as Process Development), dimana mahasiswa membangun konsep - konsep dasar dari pengalam sehari - hari, 3) Praktek Konstruksi Kognitif Konseptual (Cognitif Conceptual Construction Practice).

Banyaknya kesalahan dalam proses pembelajaran menjadi suatu permasalahan yang teramat penting. Sehingga perlu adanya pembelajaran yang tepat dalam peroses pembelajaran disekolah. Pembelajaran melalui pendekatan RMT merupakan suatu pembelajaran dengan pendekatan memediasi siswa dalam mengajar. Pendekatan Rigorous Mathematical Thinking (RMT) berdasarkan pada teori Mediated Learning Experience (MLE) dan teori sosio-kultural Vygotsky. Pembelajaran yang menerapkan pendekatan Rigorous Mathematical Thinking (RMT) menerapkan teori Vygotsky dan kriterian pokok mediasi dari teori Mediated Learning Experience (MLE) yaitu fase pengembangan kognitif (cognitive development), konten sebagai proses pengembangan (content as process development), praktek kontruksi kognitif konseptual (cognitive conceptual contruction practice). Sehingga pembelajaran yang dilakukan lebih berpusat pada student center, bukan teacher center.

Sehingga pembelajaran RMT tidak hanya dapat mengembangkan kemampuan kognitif, namun juga dapat mengembangkan kemampuan afektif. Salah satu upaya yang bisa dilakukan oleh pendidik adalah bijak dalam memilih model pembelajaran yang cocok dengan materi, kemampuan, dan karakteristik siswa. dalam proses pembelajaran yang tepat, serta diharapkan terdapat pengaruh antara kemampuan literasi statistis (melek statistis) melalui pendekatan RMT.

Tujuan pengunaan Pengetahuan Awal Matematis (PAM) dalam penelitian 
ini adalah untuk melihat apakah implementasi pembelajaran dengan pendekatan RMT dapat merata di semua kategori PAM tinggi, sedang dan rendah pada kemampuan literasi statistis mahasiswa atau hanya pada kategori literasi statistis mahasiswa untuk PAM tertentu saja. Jika implementasi pembelajaran merata di semua kategori PAM maka penelitian ini dapat digeneralisir bahwa implementasi pembelajaran dengan pendekatan RMT cocok untuk semua tingkatan kemampuan mahasiswa.

Berdasarkan latar belakang di atas maka rumusan masalah dalam penelitian ini adalah 1) apakah pencapaian kemampuan literasi statistis mahasiswa melalui pendekatan RMT lebih baik dari mahasiswa yang mendapatkan pembelajaran ekspositori?, 2) apakah peningkatan kemampuan literasi statistis mahasiswa melalui pendekatan RMT lebih baik dari mahasiswa yang mendapatkan pembelajaran ekspositori bila ditinjau secara: (a) Keseluruhan dan (b) PAM (tinggi, sedang dan rendah)?

Berdasarkan rumusan masalah di atas, maka tujuan yang ingin dicapai dalam penelitian ini adalah untuk: 1) menelaah pencapaian kemampuan literasi statistis mahasiswa melalui pendekatan RMT dan mahasiswa yang mendapat pembelajaran ekspositori, 2) menelaah peningkatan kemampuan literasi statistis mahasiswa melalui pendekatan RMT dan mahasiswa yang mendapat pembelajaran ekspositori.

Hasil penelitian ini diharapkan dapat memberikan beberapa manfaat sebagai berikut: 1) menjawab keingintahuan peneliti tentang pengaruh pembelajaran dengan pendekatan RMT terhadap kemampuan literasi statistis mahasiswa, 2) jika ternyata pengaruhnya signifikan, maka pembelajaran dengan pendekatan RMT dapat dijadikan sebagai salah satu alternatif atau pilihan yang dapat digunakan dalam pembelajaran statistik.

\section{METODE PENELITIAN}

Penelitian ini merupakan penelitian quasi experiment. Pada kuasi eksperimen random kelompok digunakan untuk menetapkan kelompok eksperimen yang menggunakan dengan pendekatan RMT dan random kelompok kontrol (kelas pembanding) yang menggunakan ekspositori. Adapun desain penelitian sebagai berikut (Ruseffendi, 2005: 52):

Kelas Eksperimen :

Kelas Kontrol

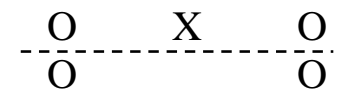

Keterangan:

$\mathrm{X}=$ pendekatan RMT

$\mathrm{O}=$ tes (pretes dan postes kemampuan literasi statistis)

--- = pengambilan sampel tidak dilakukan secara random

Populasi dalam penelitian ini adalah seluruh mahasiswa Program Studi Pendidikan Matematika pada salah satu Universitas swasta di Kota Tangerang. Sampel dalam penelitian ini adalah mahasiswa semester empat yang mengontrak matakuliah statistika II tahun 2015/2016. Pengambilan sampel dilakukan dengan purposive sampling.

Tes uraian kemampuan literasi statistis dalam penelitian ini digunakan untuk memperoleh data dalam penelitian ini. Indikator kemampuan literasi statistis yang diukur, yaitu kemampuan literasi statistis dalam menginterpretasikan informasi 
statistik dalam berbagai konteks, penyajian data statistik, menganalisis dan interpretasi serta melakukan perhitungan statistik.

Data yang telah dikumpulkan, kemudian diolah secara kuantitatif yang bertujuan menjawab kesimpulan terhadap hasil penelitian.

Berikut langkah yang dilakukan dalam mengolah data secara kuantitatif:

1. Uji prasyarat analisis yaitu uji normalitas dengan menggunakan Saphiro Wilk

2. Uji perbedaan rataan skor kemampuan literasi statistis

\section{HASIL DAN PEMBAHASAN}

Berikut ini merupakan deskripsi rata-rata kemampuan literasi statistis mahasiswa pada kelas yang menggunakan pendekatan RMT (P.RMT) dan kelas yang menggunakan pembelajaran ekspositori (P.E).

Tabel 1 memperlihatkan bahwa hasil postes yang telah dipaparkan pada Tabel 1 Kelompok RMT memiliki rata-rata yang lebih unggul dari kelompok ekspositori. Namun berdasarkan Tabel 1 varians pada skor postes pada kelompok ekspositori lebih besar dari kelompok RMT, hal ini menunjukkan bahwa skor postes kemampuan literasi statistis mahasiswa pada kelompok ekspositori cukup beragam.

Data $N$-Gain menunjukkan peningkatan kemampuan literasi statistis mahasiswa sebelum dan sesudah pembelajaran diberikan. Tabel 1 menunjukkan bahwa selisih peningkatan antara kelompok ekspositori dan kelompok RMT memiliki selisih peningkatan yang cukup berbeda yaitu, 0,48 atau $48 \%$ untuk kelompok ekspositori dan 0,70 atau 70\% untuk kelompok RMT.

Tabel 1. Statistik Deskriptif Kemampuan Literasi Statistis Kelompok Ekspositori (P.E) dan RMT (P.RMT)

\begin{tabular}{|l|c|c|c|c|c|c|}
\hline \multirow{2}{*}{ Data } & \multicolumn{2}{c|}{ Pretes } & \multicolumn{2}{c|}{ Postes } & \multicolumn{2}{c|}{ N-Gain } \\
\cline { 2 - 8 } & P.E & P.RMT & P.E & P.RMT & P.E & P.RMT \\
\hline $\boldsymbol{n}$ & 24 & 24 & 24 & 24 & 24 & 24 \\
\hline Skor Maks & \multicolumn{2}{|c|}{28} & \multicolumn{2}{c|}{28} & \multicolumn{2}{c|}{1} \\
\hline Skor Tertinggi & 13 & 11 & 25 & 27 & 0,85 & 0,95 \\
\hline Skor Terendah & 3 & 2 & 10 & 16 & 0,14 & 0,48 \\
\hline Rata-Rata & 8,38 & 5,58 & 18,71 & 21,29 & 0,48 & 0,70 \\
\hline Simpangan Baku & 2,18 & 1,84 & 3,90 & 2,49 & 0,20 & 0,11 \\
\hline
\end{tabular}

Gambar 1 di bawah ini mengambarkan perbandingan rata-rata kemampuan literasi statistis pada skor pretes, postes dan $N$-gain pada kelompok ekspositori dan kelompok RMT. Gambar 1 merupakan deskriptif dari data pretes, postes dan $N$-Gain kemampuan literasi statistis secara keseluruhan dari kelompok ekspositori dan kelompok RMT. Untuk mengetahui apakah perbedaan ini benar-benar berbeda secara signifikan, maka perlu dilakukan uji perbedaan rata-rata pada kelompok ekspositori dan kelompok RMT. 


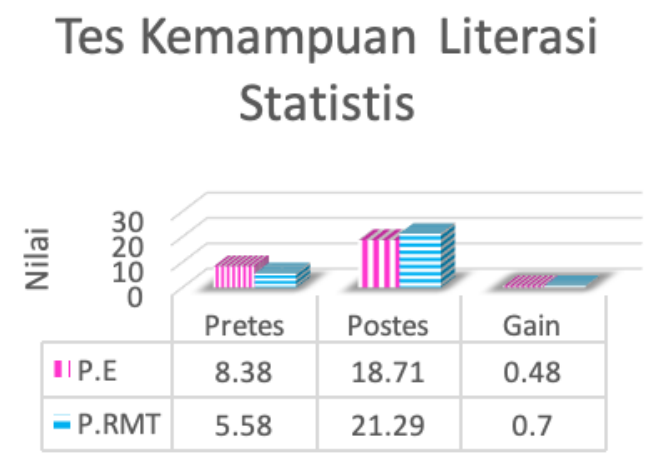

\section{Gambar 1. Perbandingan Rata-Rata Kemampuan Literasi Statistis}

Berdasarkan Tabel 2 bahwa pencapaian kemampuan literasi statistis mahasiswa yang mendapatkan pendekatan RMT lebih baik dari mahasiswa yang mendapatkan pembelajaran ekspositori. Kesimpulan ini dibuktikan dengan uji statistik terlihat bahwa nilai signifikansi (Sig. 1-tailed) sebesar 0,000 lebih kecil dari $\alpha=0,05$ sehingga menolak $\mathrm{H}_{0}$. Hasil uji statistik ini memberikan indikasi bahwa pendekatan RMT mampu memberikan kontribusi yang baik untuk kemampuan akhir literasi statistis.

\section{Tabel 2. Hasil Uji Perbedaan Dua Rata-Rata Postes Kemampuan Literasi} Statistis Mahasiswa

\begin{tabular}{|c|c|c|c|c|}
\hline $\mathbf{t}$ & $\boldsymbol{d} \boldsymbol{f}$ & Sig. (2-tailed) & Sig. (1-tailed) & Kesimpulan \\
\hline \hline$-2,737$ & 46 & 0,009 & 0,000 & $\mathrm{H}_{0}$ ditolak \\
\hline
\end{tabular}

Berdasarkan hasil uji t' pada Tabel 3 menunjukkan bahwa $\mathrm{H}_{1}$ diterima dengan menolak $\mathrm{H}_{0}$. Kesimpulan ini dibuktikan dengan uji statistik terlihat bahwa nilai signifikansi (Sig. 1-tailed) sebesar 0,000 lebih kecil dari $\alpha=0,05$ sehingga $\mathrm{H}_{0}$ ditolak. Sehingga dapat disimpulkan bahwa peningkatan kemampuan literasi statistis mahasiswa yang mendapatkan pembelajaran dengan pendekatan Rigorous Mathematical Thinking (RMT) lebih baik dari mahasiswa yang mendapatkan pembelajaran ekspositori.

Tabel 3. Hasil Uji Perbedaan Dua Rata-Rata $N$-Gain Kemampuan Literasi Statistis Mahasiswa

\begin{tabular}{|c|c|c|c|c|}
\hline $\mathbf{t}$ & $\boldsymbol{d} \boldsymbol{f}$ & Sig. (2-tailed) & Sig. (1-tailed) & Kesimpulan \\
\hline \hline$-4,704$ & 35,819 & 0,000 & 0,000 & $\mathrm{H}_{0}$ ditolak \\
\hline
\end{tabular}

Berdasarkan hasil analisis secara deskriptif dan infrensial, memberikan temuan, bahwa peningkatan dan pencapaian kemampuan literasi statistis mahasiswa yang mendapatkan pembelajaran melalui pendekatan RMT lebih baik dari mahasiswa yang mendapatkan pembelajaran ekspositori. 
Tabel 4. Hasil Uji Perbedaan Dua Rata-Rata N-Gain Berdasarkan PAM (tinggi, sedang dan rendah) Kemampuan Literasi Statistis Mahasiswa

\begin{tabular}{|l|c|c|c|c|c|c|}
\hline $\begin{array}{l}\text { Kelompok } \\
\text { Berdasarkan } \\
\text { PAM }\end{array}$ & $\begin{array}{c}\text { Uji } \\
\text { Statistik }\end{array}$ & $\boldsymbol{t}$ & $\boldsymbol{d f}$ & $\begin{array}{c}\text { Sig. } \\
\mathbf{( 2 -} \\
\text { tailed })\end{array}$ & $\begin{array}{c}\text { Sig. } \\
(\mathbf{1 -} \\
\text { tailed })\end{array}$ & Kesimpulan \\
\hline \hline Tinggi (T) & Uji-t & $-2,786$ & 10 & 0,019 & 0,009 & $\mathrm{H}_{0}$ ditolak \\
\hline Sedang (S) & Uji-t' & $-1,894$ & 9,815 & 0,088 & 0,044 & $\mathrm{H}_{0}$ ditolak \\
\hline Rendah (R) & Uji-t' & $-3,646$ & 13,546 & 0,003 & 0,000 & $\mathrm{H}_{0}$ ditolak \\
\hline
\end{tabular}

Kemampuan literasi statistis dalam penelitian ini meningkat secara signifikan melalui pendekatan RMT. Mahasiswa yang semula kurang menyukai matakuliah statistika II mulai memiliki antusias yang baik pada tiap pertemuan, meskipun belum seluruhnya mahasiswa menyukai matakuliah statistika. Hal ini sesuai dengan pandangan kontruktivisme, dimana pengetahuan tumbuh dan berkembang melalui pengalaman. (Alhaddad, 2012). Dimana melalui pendekatan RMT mahasiswa dibimbing, dan diberikan arahan, bahwa statistika bukan ilmu yang sulit untuk dipelajari, sehingga angapan akan sulitnya mempelajari statistika berubah melalui pendekatan RMT. Mahasiswa yang sudah memiliki asusmsi bahwa statistika tidak sulit, akan memiliki kemampuan literasi yang baik.

Vygotsky juga menekankan bahwa belajar dapat membangkitkan proses mental yang hanya bisa dioprasikan manakala orang berinteraksi dengan orang dewasa atau berkolaborasi sesama teman (Supriadi, 2009). Pembelajaran dikatakan efektif ketika mahasiswa dapat lebih berkembang dengan memanfaatkan infromasi yang telah diterima atau dikenal dengan istilah "Going beyond the information given" (Sabandar, 2008)

Tahapan - tahapan peroses RMT menghadapkan siswa pada masalah untuk membangun pengetahuan. Dalam setiap tahap pembelajaran ini teori Dewey yang menjelaskan bahwa dalam memecahkan masalah merupakan suatu peroses berpikir hati - hati, serta dilandasi peroses berpikir kearah kesimpulan yang definitif. Dewey juga menekankan bahwa manusia merupakan mahluk yang bebas, merdeka, kreatif serta dinamis, dan manusia memiliki kemampuan untuk bekerjasama (Rostitawati, 2014). Dengan menciptakan kondisi ini mahasiswa di arahkan untuk membangun kemampuan literasi secara tidak langsung, sehingga akan terjadi proses dimana mahasiswa mulai membangun pengetahuannya sendiri melalui lingkungan dalam peroses pembelajaran.

Dengan meningkatnya kemampuan literasi statistis pada calon guru matematika, diharapkan memiliki dampak ketika sudah menjadi guru terutama saat mengajarkan matematika pada materi statistik pada siswa. Mengingat pentingnya literasi statistis pada mahasiswa, ketika menjadi guru, maupun dalam kehidupan sehari - hari. Memberikan dampak yang positif dalam perkembangan pendidikan. Hal senada juga diungkapkan oleh Dasari (2006) bahwa bukan suatu keniscayaan masyarakat modern menuntut kemampuan literasi statistis yang memadai, sehingga perlu sedini mungkin mengajarkan analisis data statistis kepada siswa. 


\section{SIMPULAN DAN SARAN}

Berdasarkan rumusan masalah dan hasil penelitian serta pembahasan terhadap hasil-hasil penelitian sebagaimana yang diuraikan sebelumnya maka diperoleh kesimpulan dan saran dari hasil-hasil penelitian tersebut. Secara keseluruhan mahasiswa yang memperoleh pendekatan RMT kemampuan literasi statistinya lebih baik dari pada mahasiswa yang mendapatkan pembelajaran ekspositori. Mahasiswa yang memperoleh RMT peningkatan kemampuan literasi statistinya lebih baik dari pada mahasiswa yang mendapatkan pembelajaran ekspositori.

Berdasarkan kesimpulan penelitian di atas, diajukan beberapa saran sebagai berikut: 1) temuan pendekatan RMT dapat diterapkan sebagi alternatif pendekatan pembelajaran untuk meningkatkan kemampuan literasi statistis, 2) temuan pendekatan RMT tidak memberikan pengaruh peningkatan literasis statistis kepada mahasiswa berkemampuan sedang berdasarkan kategori PAM.

\section{DAFTAR PUSTAKA}

Alhaddad, I. (2012) Penerapan Teori Perkembangan Mental Piaget Pada Konsep Kekekalan Panjang. Jurnal Ilmiah Program Studi Matematika STKIP Siliwangi Bandung. Vol 1 No 1

Dasari (2006) Kemampuan Literasi Statistis dan Implikasinya Dalam Pembelajaran. Disajikan Pada Seminar Pendidikan Nasional, UNY 26 Maret 2006.

Farmer, L., \& Stricevic , I. (2011): Using research to promote literacy and reading in libraries: Guidelines for librarians. International Federation of Library Associations (IFLA).

Moore, D. S. 1997. New Pedagogy and New Content: The Case of Statistics. International Statistics Review, 65(2), 123-165

Rostitawati, T. (2014) Konsep Pendidikan Jhon Dewey. Vol. 2 No. 22014

Rumsey, D. J. (2002). Statistical literacy as a goal for introductory statistics courses. Journal of statisties education, Vol 10. Ohio State University.

Ruseffendi, H. E. T. (2005). Dasar-dasar Penelitian Pendidikan dan Bidang Non-Eksakta Lainnya. Bandung: Tarsito.

Sabandar, J. (2010) Thinking Classroom dalam pembelajaran Matematika di Sekolah [Online] Tersedia: http://file.upi.edu/Direktori/FPMIPA/JUR._PEND._MATEMATIKA/19470 5241981031-

JOZUA_SABANDAR/KUMPULAN_MAKALAH_DAN_JURNAL/Thinki ng-Classroom-dalam-Pembelajaran-Matematika-di-Sekolah.pdf

Sudjana. 2005. Metoda Statistika. Bandung: Tarsito.

Supriadi, (2012) Teori Belajar Matematika Dengan Pendidikan Matematika Indonesia. Jurnal Pendidikan Dasar no. 12 Oktober 2009.

Suryadi, D. (2007). Penggunaan Pendekatan Pembelajaran Tidak Langsung serta Pendekatan Gabungan Langsung dan Tidak Langsung dalam Rangka Meningkatkan Kemampuan Tingkat Tinggi Siswa SLTP. Disertasi Doktor 
pada PPS Universitas Pendidikan Indonesia Bandung: Tidak Diterbitkan.

Takaria, J. (2015). Peningkatan Literasi Statistis, Representasi Matematis dan Self Concept Mahasiswa Calon Guru Sekolah Dasar Melalui Model Collaborative Problem Solving. Disertasi Doktor pada SPs Universitas Pendidikan Indonesia Bandung: Tidak diterbitkan. 